\title{
INTERNAL LIPIDS OF FELTED, YELLOWED AND PATHOLOGICALLY THIN WOOL
}

\author{
V. M. TKACHUK ${ }^{1}$, V. V. HAVRYLYAK ${ }^{1}$, P. V. STAPAY ${ }^{1}$, H. M. SEDILO ${ }^{2}$ \\ ${ }^{1}$ Institute of Animal Biology, NAAS of Ukraine, Lviv; \\ ${ }^{2}$ Institute of Agriculture of Carpathian region, Obroshyno, Lviv region, Ukraine; \\ e-mail: havvita@ukr.net
}

\begin{abstract}
The keratin fibers contain small amount of the internal lipids which are in free state or bound with fiber proteins via tioester of 18-methyleicosanoic acid. Today the origin of these lipids, their composition and functional properties are still not found. Therefore, our objective was to examine the content and composition of internal lipids in sheep's wool with different defects.

We observed that regardless of the type of fibers defect there are significant changes especially in the quality composition of the internal lipids, although the total content of free and covalently bound lipids in all cases is practically identical. Notably, both free and covalently bound lipids composition of felted and simultaneously felted and yellowed wool is characterized by changes in contents mainly of free fatty acids and ceramides whereas abnormal thinning of fibers is accompanied only by a decrease of sulfolipids.
\end{abstract}

Key words: wool fiber, free and bound internal lipids, felting, yellowing, thinning.

A ccording to IWTO Market Information [1] the share of wool for the textile production in the world is only $1.5 \%$, but the cost of finished products made of it is many times higher than that of wool as a raw material and ensures the functioning of light industry, trade, transportation. However, wool is characterized by the unique properties. Even nowadays it is difficult to synthesize material which would possess similar features such as insulation, moisture absorption and respiration. In addition, wool fibers are harmless for health and capable of biodegradation.

Wool fiber (depending on water content) consists of the protein to the extent of $65-95 \%$; other components are lipids, pigments and minerals [2]. Wool fiber lipids are divided into two types: surface lipids, which provide hydrophobic properties, lubrication and shine, and endogenous lipids, which are associated with diffusion, cell adhesion and physical and chemical properties such as strength, plasticity and elasticity [3, 4]. Moreover structural lipids play an important role in permeability and barrier function, preventing the penetration of external materials into the fiber [5].

The wool fiber contains a small amount (3\%) of internal lipids. Despite the large amount of literature data, there is currently no consensus in regarding their quantitative and qualitative composition.
According to [6] internal lipids, which are synthesized in the hair matrix cells, consist of polar components such as ceramides, cholesterol sulfate and nonpolar components. Major classes of lipids are presented by cholesterol esters, cholesterol sulfate, free fatty acids, fatty alcohols, ceramides and glycosilceramides $[6,7]$.

Literature data indicate that different structural components of wool fibers contain unequal amount of lipids [8]. The cuticle and cortical cells are held together by the cell membrane complex (CMC) which forms the only continuous phase in the keratin fiber $[9,10]$. Wertz et al. [11] pointed out that intercellular lipid lamellae were located between cuticles cells and these lipid lamellae were also found inside the cortex in the boundaries of spindle cortical cells. The outer surface of the cuticle is covered with a monolayer of covalently attached fatty acids, most of which is 18-methyleicosanoic acid. The fatty acids are attached to the protein layer via thioester bonds.

It is known that both free and covalently bound lipids are lost during normal environment exposures [12]. Our preliminary data also have indicated the reduction of lipid content in the yellowed wool [13].

However, little is known about the role of internal lipids and mechanisms that potentially link structural lipids with fiber defects. Common defects of wool that impair its physicochemical and techno- 
logical properties are yellowing, felting, which occurs before the shearing of wool and abnormal thinning.

It should be noted that wool is characterized by such a unique technological feature as the ability to felt. Felting of wool underlies the production of cloth, felt boots, felt, but wool can felt on the sheep's body, which is considered as a defect.

One of major defects is the yellowing of wool, which causes are mostly known today, but the mechanism of yellowing is not yet fully revealed. Wool yellowing is characteristic of all breeds of sheep, regardless of wool cover type, but the main factors are the hot climate with high humidity, solar radiation as well as the processes occurring in the wool grease and its microflora [14].

Depression of wool growth, which is increased by physiological stress on animals caused by pregnancy or lactation and, as a result, sharp reduction of the fiber diameter, accompanied by the loss of its strength was observed in the sheep. At the same time both the cuticle and cortex were reduced.

In this study we present for the first time the comprehensive investigation of internal lipids content, their composition in the wool fibers with different defects, named felted, simultaneously felted and yellowed and pathologically thin wool.

\section{Materials and Methods}

Samples of wool. Raw Askanian fine wool and Askanian crossbred wool samples were kindly provided by PhD M. M. Svystula (M. F. Ivanov Institute of Animal Breeding in Steppe regions, «AskaniaNova»).

The samples of normal (undamaged), felted and simultaneously felted and yellowed Askanian fine fleece wool with an average diameter of $20.4 \mu \mathrm{m}$ and samples of normal (mean fiber diameter is $30.6 \mu \mathrm{m}$ ) and pathologically thinned Askanian crossbred wool (mean fiber diameter is $20.1 \mu \mathrm{m}$ ), obtained after the spring shearing of sheep were used for the analysis.

Prior to the extraction wool fibers were prepared in the laboratory as follows: wool was washed with neutral detergent solution, washed five times with warm water and twice with distilled water, then dried at room temperature and subsequently cleaned in order to remove all the contaminants. Surface lipids were extracted in the Soxhlet apparatus with carbon tetrachloride for 6 hours.

Electron-microscopic investigation. The prepared fiber was fixed onto a specimen stub and then sputter-coated with copper. The fiber was inserted into JEOL JSM-T220A Scanning Electron Microscope (Japan) operating at an accelerating voltage of $20 \mathrm{\kappa V}$ for viewing and photography.

Extraction of free internal lipids. The internal free lipids were extracted from wool $(3 \mathrm{~g})$ in the Soxhlet apparatus for 5 hours using a mixture of chloroform/methanol $(2: 1, \mathrm{v} / \mathrm{v})$. The lipid extracts were collected, evaporated to dryness and then weighed on an analytical balance.

Extraction of bound internal lipids. The extraction of bound internal lipid was performed as described [15]. For this purpose, wool samples after removal of free internal lipids were subjected to alkaline hydrolysis by heating for $2 \mathrm{~h}$ at $60^{\circ} \mathrm{C}$ with $1 \mathrm{M} \mathrm{KOH}$ in $90 \% \mathrm{CH}_{3} \mathrm{OH}$. Then the samples were cooled to room temperature and transferred to the separatory funnel, where $100 \mathrm{ml}$ of chloroform and $25 \mathrm{ml}$ of distilled water were added. After 12 hours the lower chloroform layer was taken to the flask and the upper phase, including fiber residue, was acidified by the addition $50 \mathrm{ml}$ of $6 \mathrm{M} \mathrm{HCl}$. Then acidified upper phase was mixed with $100 \mathrm{ml}$ of chloroform. Further, the combined chloroform extracts were mixed, filtered and dried by evaporation. The precipitates were dissolved in $10 \mathrm{ml}$ mixture of chloroformmethanol (2:1) and $3 \mathrm{ml} 2 \mathrm{M} \mathrm{KCl}$ containing $0.1 \mathrm{M}$ $\mathrm{HCl}$ was added to each sample. After 24 hours upper phase containing hydrophobic peptides was removed by water pump and lower phase, which contained the lipids, was filtered and dried in glass tube. The weight of lipids was then determined.

For the analysis the integral lipids were used, which are defined as the covalently bound internal lipids that can be extracted by alkali saponification, following the solvent extraction.

The lipid extract was redissolved in the chloroform/methanol mixture. The thin-layer chromatography was carried out on $0.11 \mathrm{~mm}$ thick layer of silica gel STH-1A (Sorbfil, Sorbpolymer, Russia) on $10 \times 10 \mathrm{~cm}$ polyethylen-tereftalat plates. Samples were applied $1 \mathrm{~cm}$ from the bottom edge of the plate. Chromatographic separation of internal lipids was carried out in two systems: petroleum ether/diethyl ether, $4: 1, \mathrm{v} / \mathrm{v}$ (system A) and chloroform/methanol/ water, $65: 25: 4, \mathrm{v} / \mathrm{v}$ (system B). After drying, the chromatograms are sprayed with $50 \%$ sulfuric acid and charred at $105{ }^{\circ} \mathrm{C}$. Cholesterol, stearic acid, lanosteryn (Sigma Chemical Co., USA) were used as standards.

To quantify the concentration of lipid classes the spots were scraped and transferred to a glass 
tube, where concentrated sulfuric acid was added and this mixture was heated to a temperature of $105{ }^{\circ} \mathrm{C}$. The optical density of each fraction was measured with spectrophotometer at a wavelength of $400 \mathrm{~nm}$ in $1 \mathrm{~cm}$ thick cuvette [16]. Other classes of lipids were compared with $r_{f}$-values of lipid classes according to literature data [17]. The percentage of each lipid component over the total lipids content was calculated.

Statistical analysis. Statistical evaluation of results was conducted using the arithmetic mean and standard error $(M \pm m)$ and the adequate interval for assessing the degree of probability $(P)$ using Student's criterion $(t)$. $P<0.05$.

Differences were statistically significant at

All procedures involving animals were conducted in accordance with the Guiding Principles for the Care and Use of the Research Animals.

\section{Results and Discussion}

Despite the recent advances in the investigation of fiber lipids, little attention has been paid to studies about the role of internal lipids and their composition in wool fibers with different defects.

Electron microscopic studies have shown (Fig. 1) that felted wool is characterized by disturbance of cuticle layer integrity. The exfoliation of individual flakes and deformation of their surface was observed. Cuticle cells of damaged hair are bent and torn irregularly, causing a baring of fiber surface, which apparently is primarily the result of the mechanical friction of fibers. Abnormal thinning of hair is accompanied by a simultaneous decrease in size of the cuticle and cortex and led to loss of fiber strength.

Raw wool was Soxhlet-extracted with the chloroform-methanol mixture. This procedure allowed

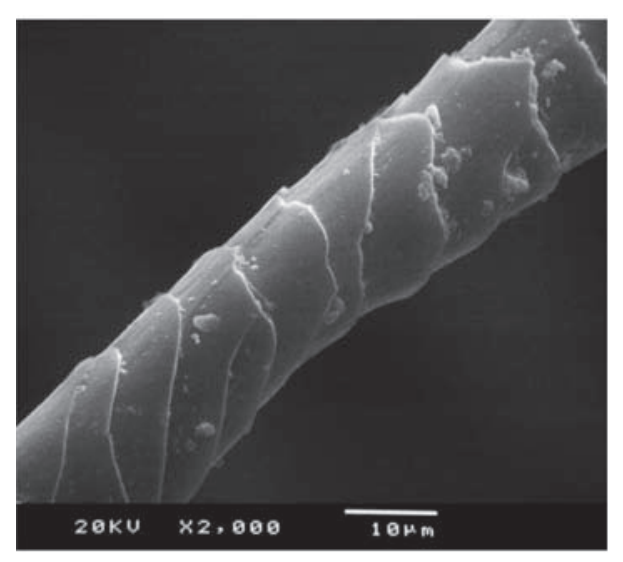

UW

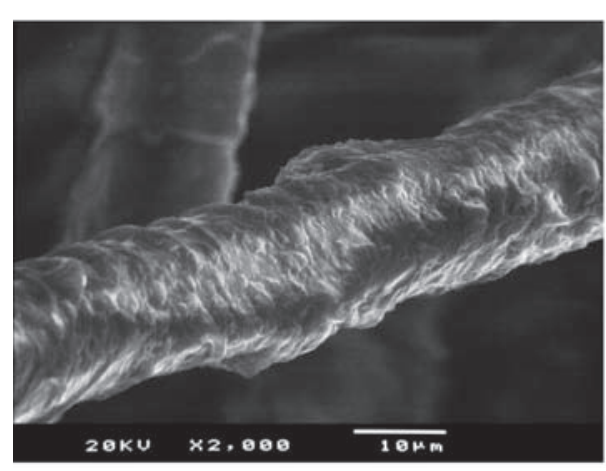

FYW

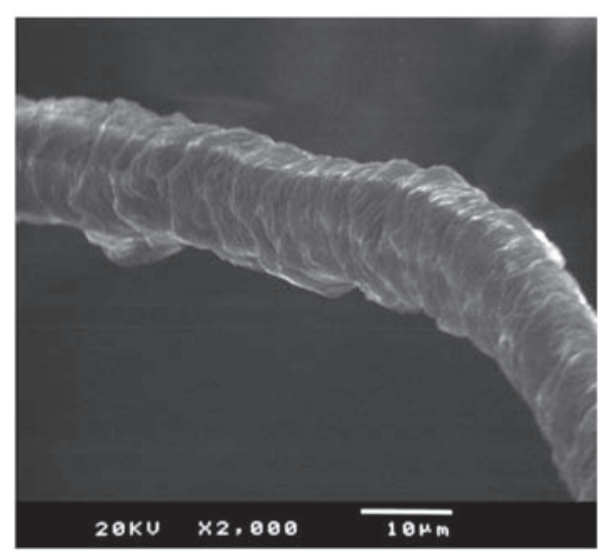

FW

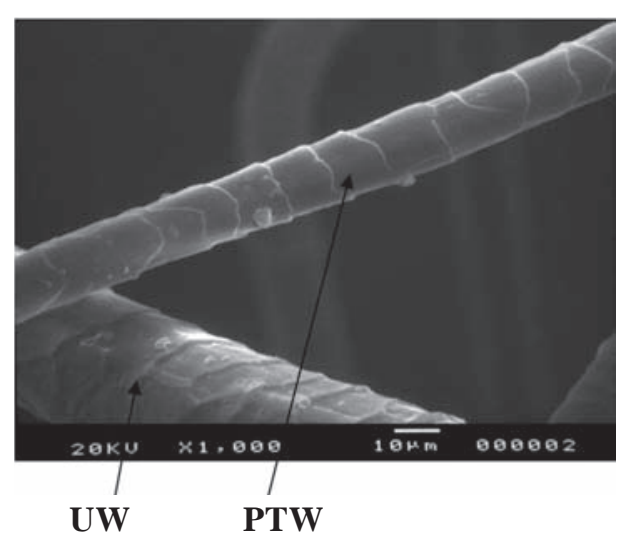

Fig. 1. Scanning electron microscopy of the outer surface of wool: UW-undamaged wool, FW-felted wool, FYW-felted yellowed wool, PTW-pathologically thin wool 
the internal free lipids to be isolated. The internal bound lipids were extracted after the fibers had been subjected to the alkaline hydrolysis. The extracted lipids were analyzed by TLC so that the main lipid classes were determined.

Our results showed (Fig. 2) that the total content of free lipids in natural (undamaged) wool of Askanian ewes was $0.92 \%$ whereas bound lipids content was twice as much $-1.76 \%$.

The content of covalently bound lipids of felted wool was significantly reduced, but at the same time the fraction of free lipids was increased by raising the amount of free fatty acids and high polar glycolipids.

Fig. 3 shows that the wool felting is accompanied by processes of oxidation and hydrolysis of lipid components, both free and covalently bound forms, as it is evidenced by reduction of cholesterol ether $(P<0.05)$ and by the increase of free fatty acids fraction $(P<0.01)$. Simultaneously felted and yellowed wool was characterized by the largest amount of free fatty acids. So yellowing increases hydrolytic processes in the fiber. Enhancement of free internal lipids content in defective fibers is apparently due to reduction of bound lipids indicating the loss of connection with protein of fibers. These data are confirmed by significant changes in the interrelation between different classes of lipids. Thus, it is important to note that the total content of free and covalently bounded lipids in undamaged, felted and felted yellowed wool fibers is almost the same $(2.68,2.65$ and $2.64 \%$, respectively).

The results presented in Fig. 4 show that the ceramides are the major part of all identified lipids, obtained in the system for polar lipids - chloroform/ methanol/water $(65: 25: 4, \mathrm{v} / \mathrm{v})$. Hair includes ceramides that are predominantly composed of nonhydroxyl or $\alpha$-hydroxyl fatty acids moiety and dihydrosphingosine moiety [7]. It was considered that ceramides may be related to apoptosis during keratinization that proceeds from living hair matrix cell to dead cuticular or cortical cells and may contribute to barrier function and water holding in hair [18]. It was established that both the free and covalently bound lipids composition of felted and felted yellowed wool fiber contains fewer of ceramides $(P<0.05)$ compared to undamaged fibers.

It was shown that covalently bound lipids contain two unidentified classes of lipids, which undergo significant changes. In particular, their amount in felted and felted yellowed wool fiber increases almost twice $(P<0.001)$.

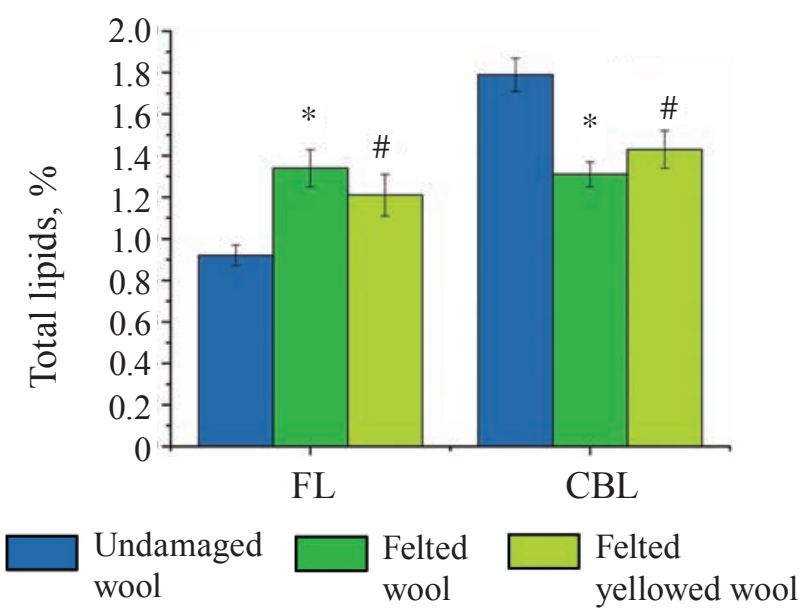

Fig. 2. The total lipids content of undamaged, felted and felted yellowed wool (FL - free lipids, CBL covalently bound lipids). This and on Fig. 3-4* difference between undamaged and felted wool is significant; \# difference between undamaged and felted yellowed wool is significant, $P \leq 0.05-0.001$

Fig. 5 shows that the total content of free lipids tends to increase in areas of abnormal fiber thinning (1.06 and $1.27 \%$ ), whereas the content of covalently bound lipids, in contrast, was higher in normal areas (1.54 and 1.24\%, respectively). But these changes are not significant and the total amount of structural lipids is almost identical for both normal and thinned fiber (2.6 and 2.51\%).

Separated in the system petroleum ether/diethyl ether $(4: 1, v / v)$ free internal lipids of wool primarily consist of free fatty acids, sterols, cholesterol and cholesterol esters (Fig. 6). In the present study it was shown that cholesterol is the dominant fraction of the free internal lipids, and cholesterol esters are the predominant fraction of the covalently bound lipids. It was also found that correlation of cholesterol to cholesterol esters is higher for pathologically thin wool areas (3.1 compared to 2.7). A tendency to increase free fatty acids in a defective fiber by reducing the part of cholesterol esters was pointed.

The changes of the covalently bound internal lipids composition mainly related to changes of cholesterol fractions. Thinning areas of fiber are characterized by lower content of cholesterol and higher content of cholesterol esters, their ratio is 0.47 and 0.55 , respectively. As well as in the case of free internal lipids there was a tendency for the increase of free fatty acids in pathologically thin fibers.

In the system chloroform/methanol/water $(65: 25: 4, \mathrm{v} / \mathrm{v})$ lipids were divided into five frac- 

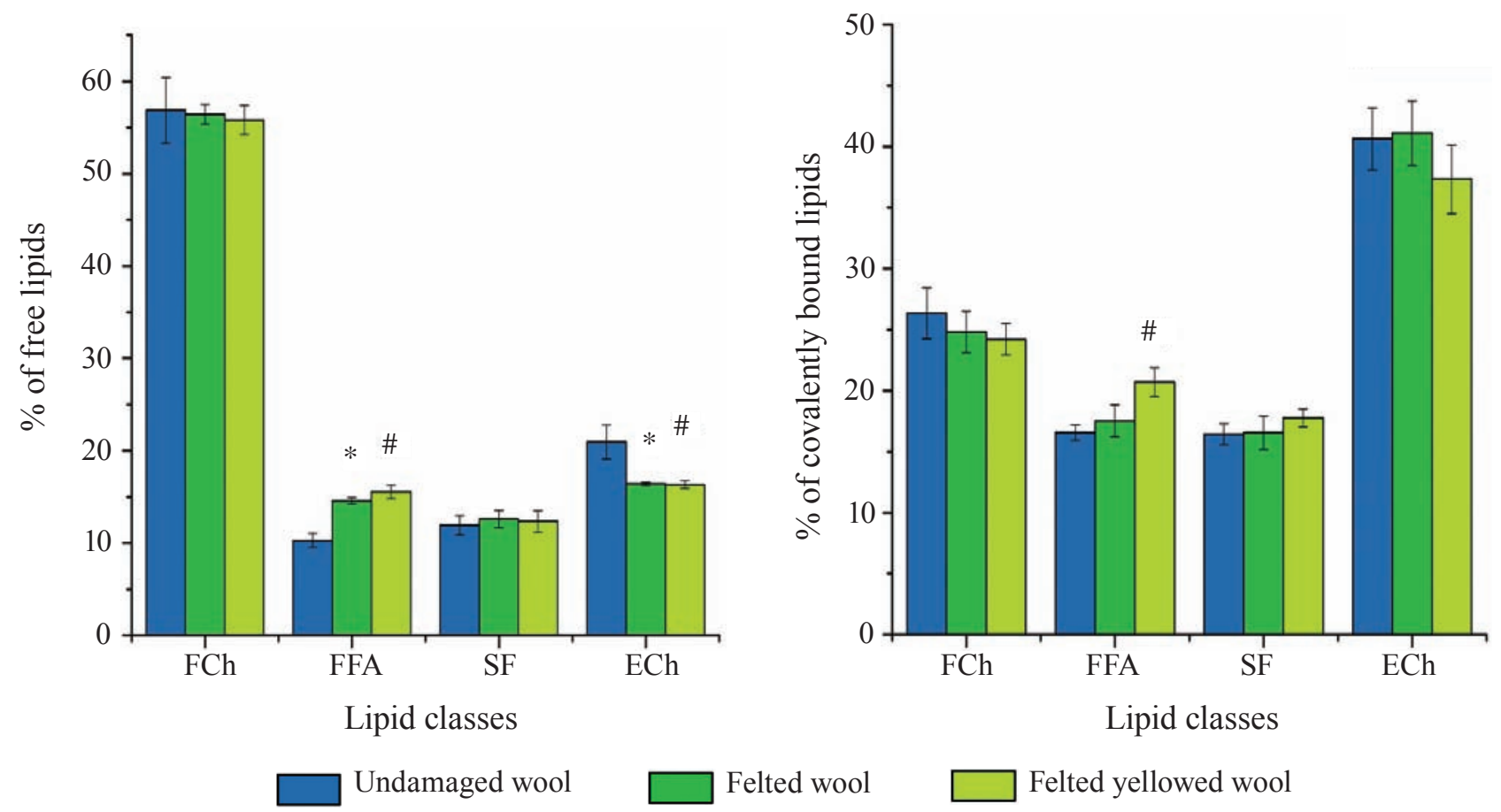

Fig. 3. Quantification of internal lipids in undamaged, felted and felted yellowed wool, obtained in system A (FCh-free cholesterol, FFA - unesterified fatty acids, SF-sterol fraction, ECh-cholesterol esters)

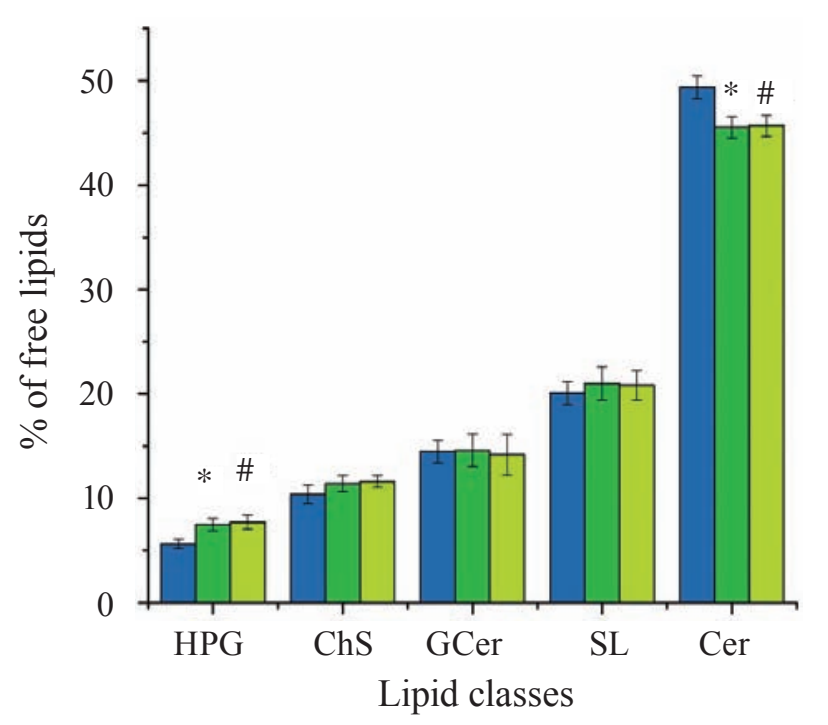

$\square$ Undamaged wool

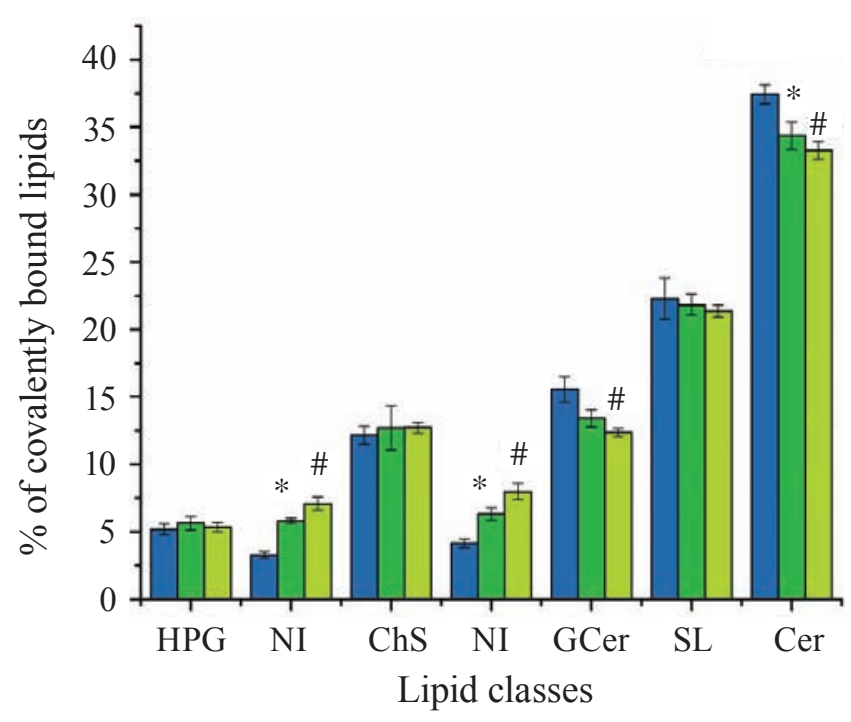

Felted wool
Felted yellowed wool

Fig. 4. Quantification of internal lipids in undamaged, felted and felted yellowed wool, obtained in system B (HPG - high polar glycolipids, NI - not identified lipids, ChS - cholesterol sulfate, GCer - glucosyl ceramides, SL - sulfolipids, Cer-ceramides)

tions, the main of which was made of ceramides (Fig. 7). The content of ceramides varied from $37 \%$ in free internal lipids to $49 \%$ in covalently bound fraction. The content of highly polar glycolipids in pathologically thin areas of wool fiber was sig- nificantly higher (7.29\% against 5.98\%), while the amount of sulfolipids decreased.

The polar lipids of keratin fibers contain lipid classes, whose content is characterized by the presence of sulfur: sulfolipids and cholesterol sul- 


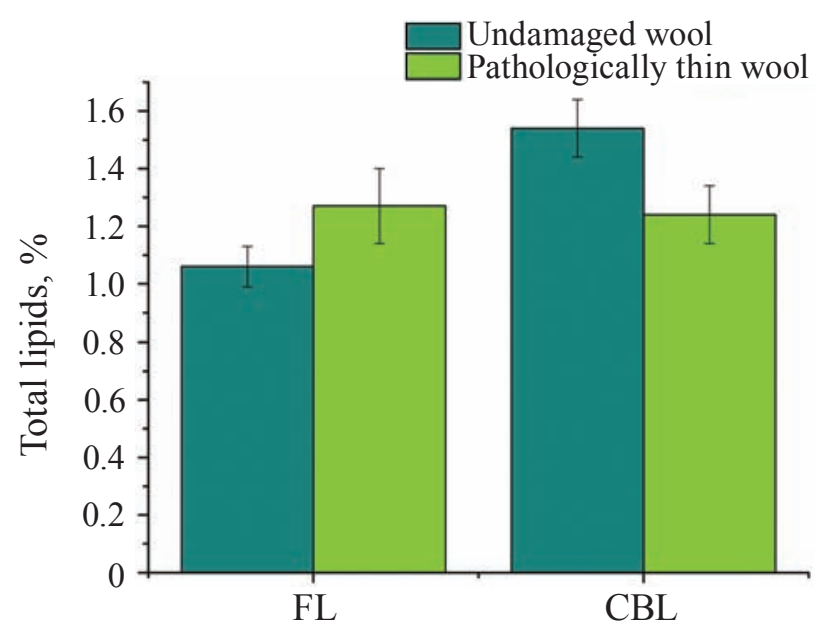

Fig. 5. The total lipids content of undamaged and pathologically thin wool (FL-free lipids, CBL-covalently bound lipids)

fate. Wertz and Downing [17] in their studies on the hair of monkey, dog, pig and quills of porcupine observed that the value of cholesterol sulfate is 22$29 \%$. Cholesterol sulfate supports the integrity of hair. The investigation of keratinization has shown that cholesterol sulfate plays an important role in the cell cohesion.

A characteristic feature of pathologically thin fibers is a decrease of sulfolipids content, and it is typical of both free and bound structural lipids.

Therefore, covalently bound lipids content is decreased in the damaged hair while the amount of free structural lipids is increased.

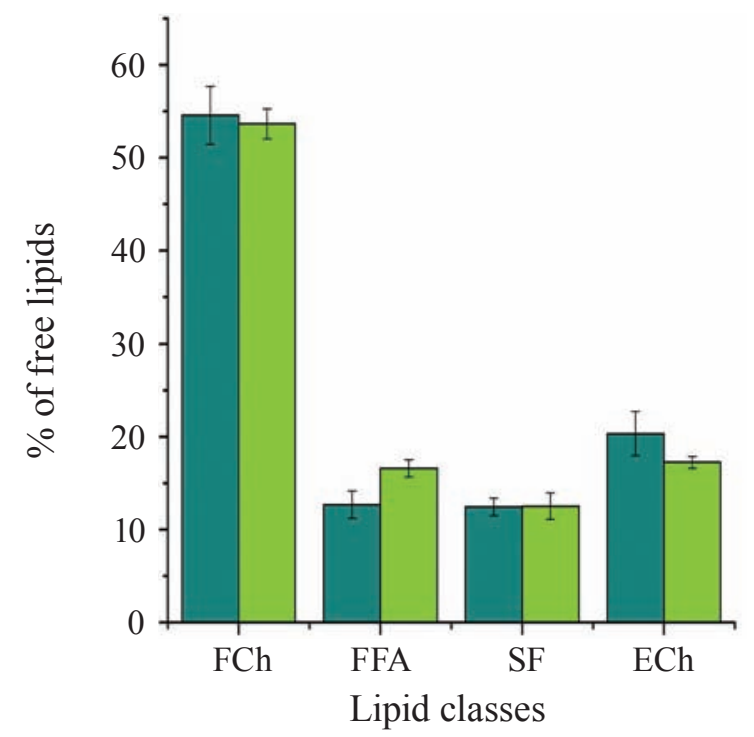

It was established that the wool felting is accompanied by processes of oxidation and hydrolysis of lipids components, which is indicated by reduction of cholesteryl esters $(P<0.05)$ in felted wool and by rise of free fatty acids fraction $(P<0.01)$.

Thibaut et al. [19] observed the decrease of ceramides content in the abraded hair. Similar data have been shown in the areas of felted and felted yellowed wool, where a lower content of ceramides takes place both in the free and covalently bound lipids $(P<0.05)$.

It was established that an abnormal thinning of wool fibers is characterized by a decrease of sulfolipids content. These data are consistent with literature, since it is known that these lipids form complexes with proteins, and such defect as abnormal hair thinning is characterized by a change in the ratio of different groups of proteins, especially high sulfur proteins [20].

In summary, we report the study of internal lipids content among wool fiber with different defects. Comparisons of such lipids composition between defective fibers may lead to a better understanding of molecular mechanisms of these defects.

It was shown that regardless of the type of fibers defect there are significant changes especially in the quality composition of the internal lipids, although the total content of free and covalently bound lipids in all cases is practically identical. Notably, the composition of both free and covalently bound lipids of felted and simultaneously felted and yel-

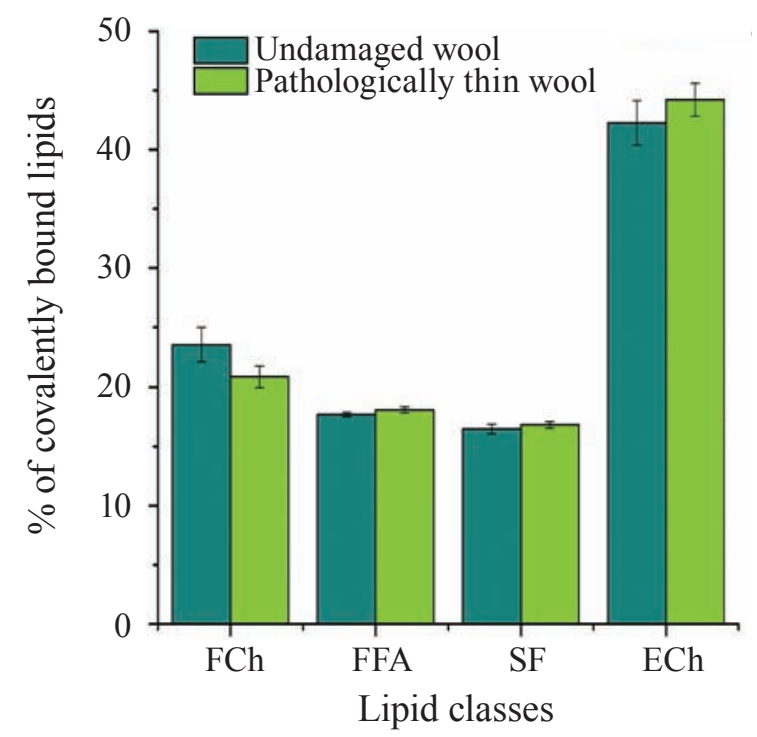

Fig. 6. Quantification of internal lipids in undamaged and pathologically thin wool, obtained in system A (FCh-free cholesterol, FFA - unesterified fatty acids, SF - sterol fraction, ECh-cholesterol esters) 

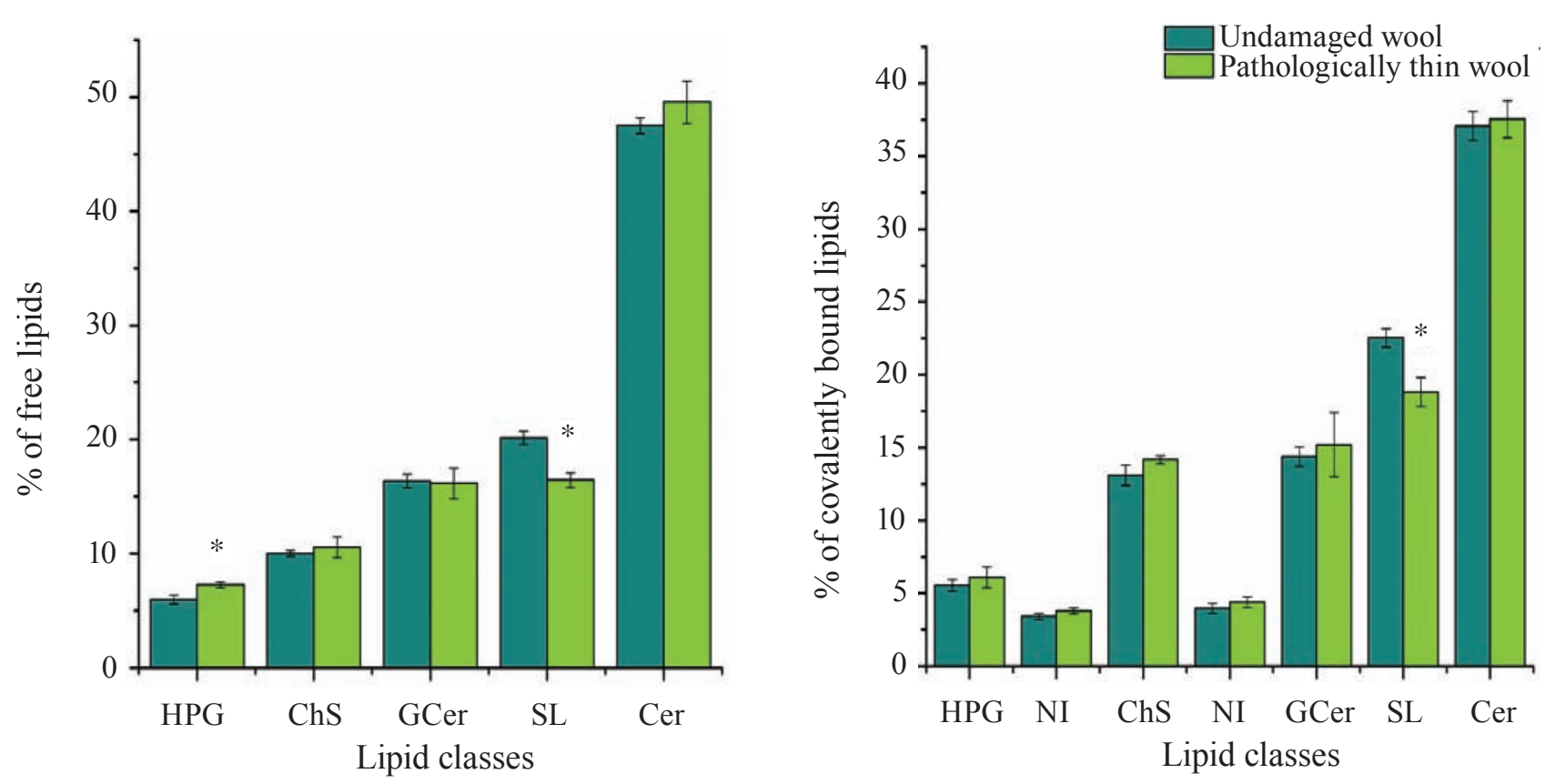

Fig. 7. Quantification of internal lipids in undamaged and pathologically thin wool, obtained in system B (HPG - high polar glycolipids, NI - not identified lipids, ChS - cholesterol sulfate, GCer - glucosyl ceramides, SL-sulfolipids, Cer-ceramides). *Difference between undamaged and pathologically thin wool is significant, $P \leq 0.05-0.001$

lowed wool is characterized by changes in contents of mainly free fatty acids and ceramides whereas the abnormal thinning of fibers is accompanied by the reduction of the sulfolipid fraction.

We thank M. M. Svystula for the samples of wool fibres and we also thank Professor I. Vudmas$k$ a for his comments on the style of English used in the article. The authors also deeply thank Professor $P$. Wertz for his valuable comments.

\section{СТРУКТУРНІ ЛІПІДИ ЗВАЛЯНӦ̈, ПОЖОВТІЛОЇ ТА ПАТОЛОГІЧНО СТОНШЕНОЇ ВОВНИ}

\section{В. М. Ткачук ${ }^{1}$ В. В. Гавриляк ${ }^{1}$, П. В. Стапай ${ }^{1}$ Г. М. Седіло}

\footnotetext{
${ }^{1}$ Інститут біології тварин НААН України, Львів; ${ }^{2}$ Інститут сільського господарства Карпатського регіону НААН України, с. Оброшино, Львівська обл.; e-mail: havvita@ukr.net
}

У кератинових волокнах частина структурних ліпідів знаходиться у вільному стані, a інша через 18-метилейкозанову кислоту зв'язана тіоефірним зв'язком із протеїнами волоса. На сьогодні остаточно ще не встановлено походження цих ліпідів, їхній склад та функціональні властивості. Тому нашим завданням було дослідити вміст та склад вільних і зв'язаних внутрішніх ліпідів у вовні овець із різними дефектами.

Установлено, що у вовняних волокнах незалежно від виду дефекту мають місце істотні зміни в якісному складі структурних ліпідів, проте загальний вміст вільних і зв'язаних ліпідів у всіх випадках є практично ідентичний. Характерно, що в складі як вільних, так і зв'язаних структурних ліпідів зваляної та одночасно зваляної і пожовтілої вовни зміни стосуються в основному вмісту вільних жирних кислот та церамідів, тоді як патологічне стоншення вовняного волокна супроводжується зменшенням вмісту сульфоліпідів.

Ключов і слова: вовняне волокно, вільні і зв'язані структурні ліпіди, звалювання, пожовтіння, стоншення. 


\section{СТРУКТУРНЫЕ ЛИПИДЫ СВАЛЯНОЙ, ПОЖЕЛТЕВШЕЙ И ПАТОЛОГИЧЕСКИ ИСТОНЧЕННОЙ ШЕРСТИ}

В. М. Ткачук ${ }^{1}$ В. В. Гавриляк ${ }^{1}$, П. В. Стапай' Г. М. Седило

${ }^{1}$ Институт биологии животных НААН Украины, Львов;

${ }^{2}$ Институт сельского хозяйства Карпатского региона НААН Украины,

с. Оброшино, Львовская обл.; e-mail: havvita@ukr.net

В кератиновых волокнах часть структурных липидов находится в свободном состоянии, а другая часть с помощью 18-метилэйкозановой кислоты связана с протеинами волоса. На сегодня окончательно не установлено происхождение этих липидов, их состав и функциональные свойства. Поэтому нашей задачей было исследовать содержание и состав свободных и связанных внутренних липидов в шерсти овец с различными дефектами.

Установлено, что в шерстяных волокнах независимо от вида дефекта выявлены существенные изменения в качественном составе структурных липидов, однако общее содержание свободных и связанных липидов во всех случаях практически идентично. Показано, что в составе как свободных, так и связанных структурных липидов свалянной и одновременно свалянной и пожелтевшей шерсти изменения касаются в основном содержания неэстерифицированных жирных кислот и церамидов, тогда как патологическое истончение шерстяного волокна сопровождается уменьшением содержания сульфолипидов.

К л юч е вы е с л о в а: свободные и связанные структурные липиды, шерсть, свойлачивание, пожелтение, истончение.

1. Poimena Analysis and Delta Consultants: IWTO Market Information 2011 [Electronic resource] / Regime of access : http://www.iwto.org/ uploaded/publications/Order_Forms/IWTO_ Market_Information_2011
2. Horvath A. L. // Sci. World J. - 2009. - 9. P. 255-271.

3. Coderch L., Mendez S., Barba C. et al. // Chem. Phys. Lipids. - 2008. - 115. -P. 1-6.

4. Cornellison C. D., Dyer J. M., Krsinic G. L., Clerens S. // Int. J. Trichology. - 2011. - 3, N 1. P. 25-27.

5. Mendez S., Marti M., Barba C. et al. // Langmuir. - 2007. - 23. - P. 1359-1364.

6. Cruz C. F., Fernandes M. M., Gomes A. C. et al. // Int. J. Cosmet. Sci. - 2013. - 35. - P. 244-249.

7. Masukawa Y., Narita H., Imokawa G. // Int. J. Cosmet. Sci. - 2005. - 56. - P. 1-16.

8. Lee W.S., Oh T. H., Chun S. H. et al. // J. Invest. Dermatol. - 2005. - 10. - P. 234-237.

9. Coderch L., Bondia I., Fonollosa J. et al. // IFSCC. - 2003. - 6. - P. 117-123.

10. Zahn H., Wortmann F.-J., Wortmann G. et al. Wool. - Weinheim: Wiley-VCH VerlagGmbH \& Co. KgaA, 2005. - 35 p.

11. Wertz P. W. // Exp. Suppl. - 1995. - 78. - P. 227237.

12. Duvel D., Chun H., Deppa D., Wertz P. // Int. J. Cosmet. Sci. - 2005. - 27, I. 4. - P. 193-197.

13. Ткачук В. М. // Вісник Причорномор'я. - 2011.4(61), № 1. - С. 193-196.

14. Константинова О. Л., Бишингалиева 3. Г. // Овцы. Козы. Шерстяное дело. - 2008. - 1. C. 34-37.

15. Wertz P. W., Downing D. T. // Lipids. - 1988. 23, N 9. - P. 878-881.

16. Marsh J. B., Weinstein D. B. // Lipid Res. 1966. - 77. - P. 574-576.

17. Wertz P.W., Downing T. D. // Comp. Biochem. Physiol. - 1998. - 92 (4). - P. 759-761.

18. Masukawa Y., Tsujimura H., Narita H. // J. Lipid Res. - 2006. - 47. - P. 1559-1571.

19. Thibaut S., de Becker E., Bernard B. A. et al. // Int. J. Cosmet. Sci. - 2010.- 32. - P. 422-434.

20. Robbins C. R. Chemical Composition of Different Hair Types. In: Chemical and physical behavior of human hair. - New York, Berlin Heidelberg: Springer-Verlag, 2012. - P. 105-176.

Received 15.07.2013 